\title{
The boron-oxygen core of borinate esters is responsible for the store-operated calcium entry potentiation ability
}

\author{
Olivier Dellis ${ }^{1,2^{*}}$, Pierre Mercier ${ }^{1}$, Christine Chomienne ${ }^{1}$
}

\begin{abstract}
Background: Store-Operated Calcium Entry (SOCE) is the major $\mathrm{Ca}^{2+}$ ion entry pathway in lymphocytes and is responsible of a severe combined immunodeficiency (SCID) when deficient. It has recently been observed or highlighted in other cell types such as myoblasts and neurons, suggesting a wider physiological role of this pathway. Whereas Orai1 protein is considered to be the channel allowing the SOCE in T cells, it is hypothesized that other proteins like TRPC could associate with Orai1 to form SOCE with different pharmacology and kinetics in other cell types. Unraveling SOCE cell functions requires specific effectors to be identified, just as dihydropyridines were crucial for the study of $\mathrm{Ca}^{2+}$ voltage-gated channels, or spider/snake toxins for other ion channel classes. To identify novel SOCE effectors, we analyzed the effects of 2-aminoethyl diphenylborinate (2-APB) and its analogues. 2-APB is a molecule known to both potentiate and inhibit T cell SOCE, but it is also an effector of TRP channels and endoplasmic reticulum $\mathrm{Ca}^{2+}$-ATPase.

Results: A structure-function analysis allowed to discover that the boron-oxygen core present in 2-APB and in the borinate ester analogues is absolutely required for the dual effects on SOCE. Indeed, a 2-APB analogue where the boron-oxygen core is replaced by a carbon-phosphorus core is devoid of potentiating capacity (while retaining inhibition capacity), highlighting the key role of the boron-oxygen core present in borinate esters for the potentiation function. However, dimesityl borinate ester, a 2-APB analogue with a terminal B-OH group showed an efficient inhibitory ability, without any potentiating capacity. The removal or addition of phenyl groups respectively decrease or increase the efficiency of the borinate esters to potentiate and inhibit the SOCE. mRNA expression revealed that Jurkat T cells mainly expressed Orai1, and were the more sensitive to 2-APB modulation of SOCE.

Conclusions: This study allows the discovery of new boron-oxygen core containing compounds with the same ability as 2-APB to both potentiate and inhibit the SOCE of different leukocyte cell lines. These compounds could represent new tools to characterize the different types of SOCE and the first step in the development of new immunomodulators.
\end{abstract}

\section{Background}

In lymphocytes, after $\mathrm{T}$ or $\mathrm{B}$ cell receptor cross-linking, inositol 1,4,5-trisphosphate $\left(\mathrm{IP}_{3}\right)$ is synthesized [1] and induces $\mathrm{Ca}^{2+}$ ion release from the lumen of the endoplasmic reticulum (ER), allowing the opening of $\mathrm{Ca}^{2+}$ selective plasma membrane channels, known as storeoperated channels (SOC). The resulting increase of the intracellular calcium concentration $\left(\left[\mathrm{Ca}^{2+}\right]_{\mathrm{i}}\right)$ allows

\footnotetext{
* Correspondence: olivier.dellis@inserm.fr

'INSERM UMR-S 940, Institut Universitaire d'Hématologie - Université Denis

Diderot Paris 7, Hôpital Saint Louis, Paris, France

Full list of author information is available at the end of the article
}

activation of NFAT (Nuclear Factor of Activated T cells) [2]. Inhibition of this Store-operated Calcium Entry (SOCE) by SKF96365 impairs T lymphocyte activation and subsequently interleukin 2 synthesis [3]. Recent studies have described two proteins playing key roles in SOCE: STIM1 and Orai1. STIM1, present in the ER membrane, senses the luminal $\mathrm{Ca}^{2+}$ concentration, and translocates near the plasma membrane during $\mathrm{Ca}^{2+}$ release, where it directly interacts with Orai1 protein forming the channel pore [4-6]. The R91W mutation of Orai1 renders the channel non-functional, and is responsible of a severe immunodeficiency [4]. Two Orai1
Ciomed Central

(C) 2011 Dellis et al; licensee BioMed Central Ltd. This is an Open Access article distributed under the terms of the Creative Commons Attribution License (http://creativecommons.org/licenses/by/2.0), which permits unrestricted use, distribution, and reproduction in any medium, provided the original work is properly cited. 
homologue genes have been described, Orai2 and Orai3. When expressed in HEK293 cells (with STIM1), the three Orai are able to produce or increase the SOCE [7]. However, despite their high homology, only Orai1 is able to restore the SOCE of SCID T cells $[4,8]$. Furthermore, Orai2 and Orai3 could show slight differences in kinetics and pharmacology.

Due to the key role of $\mathrm{Ca}^{2+}$ influx in lymphocyte activation and proliferation, the use of effectors to modulate the Orail-containing channels has appeared as a new and promising way to modulate lymphocyte activities and could represent a new way for the treatment of inflammatory diseases $[9,10]$. Although several pharmaceutical companies have developed molecules acting on SOCE, no specific SOCE effectors have been characterized [11].

One of the most interesting and promising molecule is a boron-containing molecule, 2-aminoethyl diphenylborinate (2-APB). 2-APB was originally described as a plasma membrane permeant inhibitor of $\mathrm{IP}_{3}$ receptors in human platelets and neutrophils [12], however it also impairs Sarcoplasmic-Endoplasmic Reticulum $\mathrm{Ca}^{2+}$ ATPase activity at high concentrations $(\mathrm{Kd}>200 \mu \mathrm{M})$, inducing a store $\mathrm{Ca}^{2+}$ leak [13-15] and directly blocks SOCE in the same range of concentration as for $\mathrm{IP}_{3}$ receptor inhibition [16]. Furthermore, 2-APB has a dual effect on Jurkat T cell SOCE: potentiation at low concentration $(1-5 \mu \mathrm{M})$ and inhibition at $>50 \mu \mathrm{M}$ [17]. Similar behaviour has been described on human $\mathrm{T}$, rat basophilic leukemic RBL-2H3 and chicken B DT40 cells $[4,17,18]$. 2-APB is also able to activate members of the TRP channel family at high concentrations $(100 \mu \mathrm{M}$, TRPV1, V2 and V3 $[19,20])$ and to inhibit some others (TRPC3, C6 and C7 [21]). The effects of 2-APB on SOCE has been extensively studied in $\mathrm{T}$ cells but data on other cell types of hematopoietic origin is poorly documented.

Recently, several works have been published on 2-APB analogues. Thus, several analogues of 2-APB (1; Figure 1) have been described and tested on platelets and $\mathrm{CHO}$ cells, where 2 -APB and analogues are only inhibitory [22-24]. On these cells, the boron-oxygen core (BOC) was shown not to be an absolute prerequisite for inhibition, but minor changes of the structure of 2-APB (such as replacement of the boron by a carbon atom and the terminal $\mathrm{NH}_{2}$ by a $\mathrm{N}\left(\mathrm{CH}_{3}\right)_{2}$ as in diphenhydramine) result in the loss of SOCE inhibitory activity [23]. Diphenylborinic anhydride (DPBA, 2; Figure 1) and 2,2-diphenyltetrahydrofuran (DPTHF, 3; Figure 1), two analogues lacking the aminoethyl group were still efficient showing that the aminoethyl group plays no role in SOCE inhibition by 2-APB at least in platelets [23]. More recently, Mikoshiba's group realized the synthesis of 2-APB dimers, some of which demonstrated a 20-45 fold

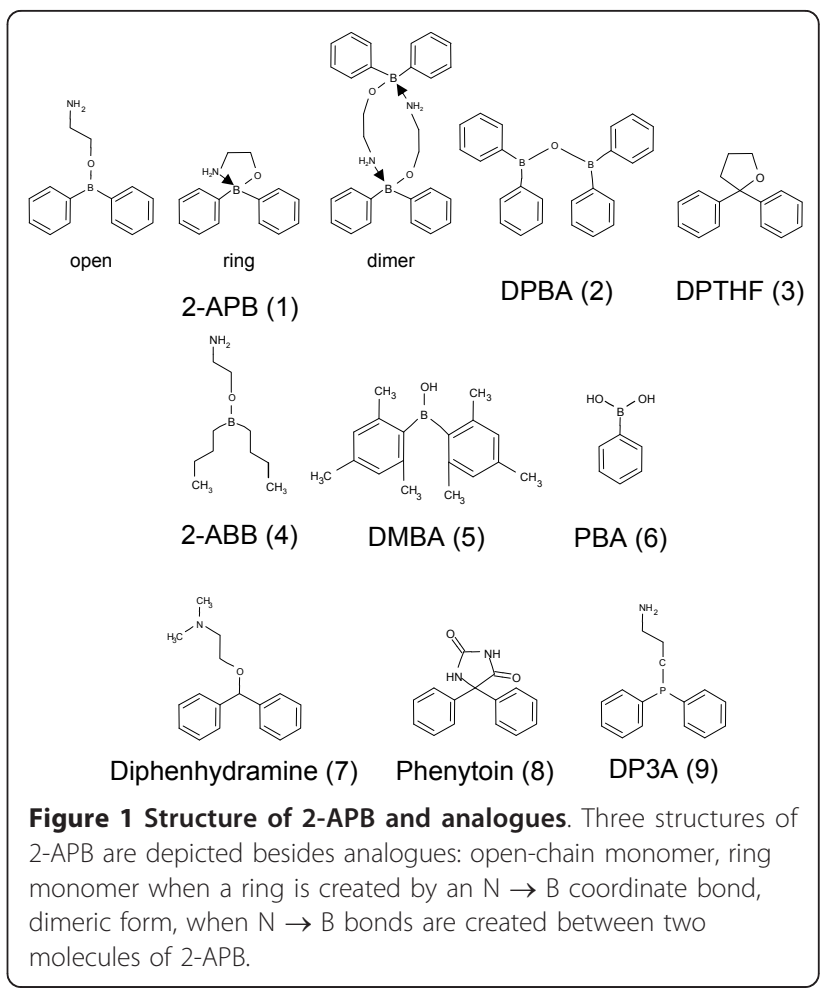

increase in inhibition capacity [25]. However, no structure-function studies have been performed on SOCE potentiation ability of 2-APB analogues.

The aim of this study was to identify which part of the 2-APB molecule is required for potentiation (and inhibition) of SOCE by using analogues modified in the three parts of the molecule: the BOC, the ethanolamine group and the phenyl rings. We show that the $\mathrm{BOC}$ is an absolute requirement for the potentiating ability of 2-APB (but not for the inhibitory capacity), and that the number of phenyl rings is linked to the capacity of the molecule to potentiate/inhibit. We also confirm that the ethanolamine group is not required for potentiation and inhibition of SOCE in other cells.

\section{Results}

Dual effects of borinate esters (2-APB, DPBA and 2-ABB) on SOCE

To visualize the SOCE, we treated the cells with $1 \mu \mathrm{M}$ thapsigargin (TG) in a $\mathrm{Ca}^{2+}$-free medium during 10 min: this treatment allows the release of $\mathrm{Ca}^{2+}$ ions from the ER (Figure 2A), and subsequently the opening of the Store-Operated Channels (SOC). Addition of $1 \mathrm{mM}$ $\mathrm{CaCl}_{2}$ then induced an increase of the intracellular $\mathrm{Ca}^{2+}$ concentration $\left(\left[\mathrm{Ca}^{2+}\right]_{\mathrm{i}}\right)$ due to the entry of $\mathrm{Ca}^{2+}$ ions through SOC. As previously described in human Jurkat $\mathrm{T}$ [17] and chicken DT40 B cells [18], 2-APB has dual effects on human BL41 B cell SOCE: potentiation at $10 \mu \mathrm{M}$ (208 $\pm 8 \%$ ), inhibition at $50 \mu \mathrm{M}$ (Figure $2 \mathrm{~A}$ and $2 \mathrm{C}$ ). As $\left[\mathrm{Ca}^{2}\right.$ 

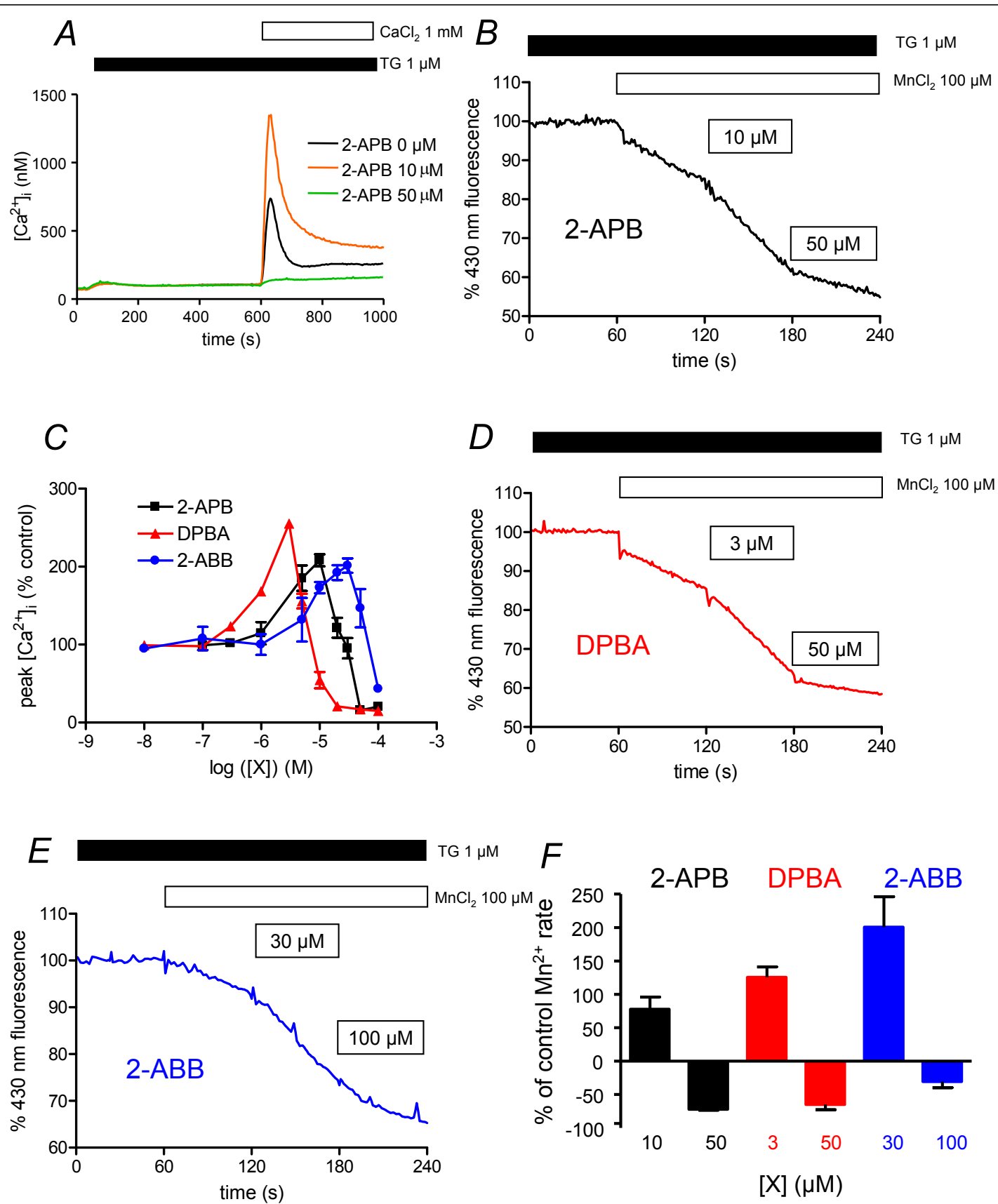

Figure 2 Borinate esters have dual effects on store-operated calcium entry. A. Cytosolic calcium concentration measurement of BL41 cells using indo-1 fluorescence. Cells were treated 10 min with TG $1 \mu \mathrm{M}$ to allow Ca ${ }^{2+}$ release from ER and opening of SOC channels. After 10 min, 1 $\mathrm{mM} \mathrm{CaCl} 2$ was re-added, allowing $\mathrm{Ca}^{2+}$ entry through SOC channels. Different 2-APB concentrations were applied $30 \mathrm{~s}$ prior to $\mathrm{CaCl}_{2}$. Error bars were omitted for clarity (maximum $\sim \pm 70 \mathrm{nM}$ ). B. $\mathrm{Mn}^{2+}$ quenching of indo-1 in BL41 cells stimulated by potentiating and inhibitory concentrations of 2-APB. Cells were pre-treated 10 min with TG $1 \mu \mathrm{M}$ allowing $\mathrm{Ca}^{2+}$ release from ER and opening of SOC channels. $60 \mathrm{~s}$ after beginning of the recordings, $100 \mu \mathrm{M} \mathrm{MnCl}_{2}$ was added. At $120 \mathrm{~s}$, potentiating concentration of 2-APB (10 $\left.\mu \mathrm{M}\right)$ was added, followed $60 \mathrm{~s}$ later by inhibiting concentration of $50 \mu \mathrm{M}$. Fluorescence of indo-1 was recorded at $430 \mathrm{~nm}$. Results expressed relative fluorescence prior to $\mathrm{MnCl}_{2}$ adding. C. 2-APB, DPBA and 2-ABB concentrations differently regulate SOCE of BL-41 cells. Experiments were done as in figure $1 \mathrm{~A}$, and peak [Ca ${ }^{2}$ $\left.{ }^{+}\right]_{i}$ was expressed as $\%$ of peak $\left[\mathrm{Ca}^{2+}\right]_{\mathrm{i}}$ recorded in absence of any borinate ester compounds. Borinate ester compounds were added $30 \mathrm{~s}$ prior to $\mathrm{CaCl}_{2}$. D. $\mathrm{Mn}^{2+}$ quenching of indo-1 in BL41 cells stimulated by potentiating and inhibitory concentrations of DPBA. Same as in figure 2B, except that 3 and $50 \mu \mathrm{M}$ DPBA were used. E. $\mathrm{Mn}^{2+}$ quenching of indo-1 in BL41 cells stimulated by potentiating and inhibitory concentrations of 2-ABB. Same as in figure 2B, except that 30 and $100 \mu \mathrm{M}$ 2-ABB were used. F. Values of Indo-1 quenching in presence of the borinate esters were normalised to values obtained in the lonely presence of $\mathrm{Mn}^{2+}$ ions. 
$\left.{ }^{+}\right]_{\mathrm{i}}$ is the result of an equilibrium between $\mathrm{Ca}^{2+}$ ion influx and $\mathrm{Ca}^{2+}$ efflux, we calculated a $\mathrm{Ca}^{2+}$ ion influx rate when the $\mathrm{Ca}^{2+}$ efflux is greatly reduced [26]. During the first 10-20 s after $\mathrm{CaCl}_{2}$ adding, $\left[\mathrm{Ca}^{2+}\right]_{\mathrm{i}}$ is still low and the $\mathrm{Ca}^{2+}$ pump activity to extrude $\mathrm{Ca}^{2+}$ from the cell is greatly reduced, meaning variations of $\left[\mathrm{Ca}^{2+}\right]_{\mathrm{i}}$ are due to $\mathrm{Ca}^{2+}$ ion influx. The rate was twofold increased in the presence of $10 \mu \mathrm{M} 2-\mathrm{APB}(32.4 \pm 7.8 \mathrm{nM} / \mathrm{s}$ vs. $62.5 \pm 11.5 \mathrm{nM} / \mathrm{s})$. In the presence of $50 \mu \mathrm{M} 2-\mathrm{APB}$, the $\mathrm{Ca}^{2+}$ influx rate was largely decreased $(<1 \mathrm{nM} / \mathrm{s})$ and the $\left[\mathrm{Ca}^{2+}\right]_{\mathrm{i}}$ increase after $\mathrm{CaCl}_{2}$ adding was largely blunted (Figure $2 \mathrm{~A}$ ).

These results were confirmed by indo-1 quenching experiments with $\mathrm{Mn}^{2+}$ ions: as $\mathrm{Mn}^{2+}$ ions enter the cells by the same channels as $\mathrm{Ca}^{2+}$ ions, they can not be pumped back to the external medium by the plasma membrane $\mathrm{Ca}^{2+}$ ATPases (PMCA) and lead to indo-1 fluorescence quenching at $430 \mathrm{~nm}$ [27]. After $10 \mathrm{~min}$ treatment by TG to open SOC, addition of $100 \mu \mathrm{M}$ $\mathrm{MnCl}_{2}$ led to a rapid decrease of $430 \mathrm{~nm}$ fluorescence (Figure 2B). The quenching was twofold increased in the presence of $10 \mu \mathrm{M} 2$-APB (decrease of indo-1 430 $\mathrm{nm}$ fluorescence by $-0.39 \pm 0.03 \% / \mathrm{s} v s .-0.22 \pm 0.01 \% / \mathrm{s})$, but decreased with $50 \mu \mathrm{M} 2-\mathrm{APB}(-0.06 \pm 0.01 \% / \mathrm{s} v s$. $-0.22 \pm 0.01 \% / \mathrm{s}$, Figure $2 \mathrm{~B})$. In BL41 cells and the absence of TG, $\mathrm{CaCl}_{2}$ addition induced a slight increase of $\left[\mathrm{Ca}^{2+}\right]_{i}$ (not shown). Thus, these experiments show for the first time that 2-APB directly acts on $\mathrm{Ca}^{2+}$ ion entry through SOC in the human B cell line BL41, with dual effects, potentiation at low, inhibition at higher concentrations.

Diphenylborinic anhydride (DPBA) and 2-aminoethyl dibutylborinate (2-ABB, 4; Figure 1) have also dual effects on BL41 cell SOCE (Figure 2C). DPBA, a 2-APB analogue with two pairs of diphenylborinate, has recently been shown to inhibit platelet SOCE [23]. In BL41 cells, when DPBA was added, maximal potentiation of SOCE was observed at $3 \mu \mathrm{M}$, whereas inhibition was at concentrations higher than $10 \mu \mathrm{M}$ (Figure 2C). Furthermore, DPBA appeared to potentiate SOCE activity with a slightly greater efficacy than 2-APB (255 vs. $208 \%)$. Thus, BL41 cell SOCE was three times more sensitive to the enhancing and inhibitory effects of DPBA than with 2-APB (Figure 2C). These results were confirmed by indo-1 quenching experiments (Figure 2D): $\mathrm{Mn}^{2+}$ quenching was twofold accelerated with $3 \mu \mathrm{M}$ DPBA $(-0.35 \pm 0.02 \% / \mathrm{s} v$ s. $-0.17 \pm 0.01 \% / \mathrm{s})$ and slowed by $50 \mu \mathrm{M}(-0.06 \pm 0.02 \% / \mathrm{s} v s .-0.17 \pm 0.01 \% / \mathrm{s})$.

$2-\mathrm{ABB}$, another 2-APB analogue where the two phenyl rings are replaced by two butyl groups, was further shown to have a dual effect on BL41 cell SOCE (Figure 2C), with a maximum of potentiation at $30 \mu \mathrm{M}(201 \pm 9 \%)$, and inhibition at $>50 \mu \mathrm{M}$. Potentiation capability was in the same order of magnitude than 2-APB's (201 vs. 208\%), but slightly weaker than DPBA's (201 vs. 255\%). BL41 SOCE sensitivity to 2-ABB is weaker than for DPBA and 2-APB (Figure 2C). Indo-1 quenching by $\mathrm{Mn}^{2+}$ ions confirmed this result: $30 \mu \mathrm{M} 2-\mathrm{ABB}$ accelerated the quenching $(-0.32 \pm 0.02 \% / \mathrm{s} v s$. $-0.12 \pm 0.01 \% / \mathrm{s})$, when 100 $\mu \mathrm{M}$ slowed it (Figure 2E, $-0.07 \pm 0.02 \% / \mathrm{s}$ vs. $-0.12 \pm$ $0.01 \% / \mathrm{s})$.

\section{Differential effects of dimesitylborinic acid (DMBA) and phenylboronic acid (PBA) on SOCE}

As diphenylborinic acid is unstable, we chose dimesitylborinic acid (DMBA, 5; Figure 1) which is commercially available and stable. This compound is a 2-APB molecule without an ethanolamine group (and subsequently with a terminal $\mathrm{B}-\mathrm{OH}$ ), and where the two phenyl rings are replaced by two mesityl groups. DMBA was not able to potentiate SOCE at 2-APB potentiating concentrations, but clearly showed an efficient inhibitory capacity $\left(K_{\mathrm{i}} \approx 4 \mu \mathrm{M}\right.$, Figure 3A). Indeed, DMBA was close to the efficiency obtained with SKF96365, another common SOCE inhibitor $\left(K_{\mathrm{i}} \approx 3.3 \mu \mathrm{M}\right.$, not shown). The inhibitory capacity was confirm by $\mathrm{Mn}^{2+}$ quenching of indo-1: $1 \mu \mathrm{M}$ DMBA $(-0.13 \pm 0.01 \% / \mathrm{s} v s .-0.17 \pm 0.01 \% / \mathrm{s})$, $20 \mu \mathrm{M}$. $(-0.08 \pm 0.01 \% / \mathrm{s} v s .-0.17 \pm 0.01 \% / \mathrm{s}$, Figure $3 \mathrm{~B})$. As 2-APB and DMBA act in the same range of concentrations, we performed competition experiments. Used at $10 \mu \mathrm{M}, 2-\mathrm{APB}$ was potentiating, DMBA inhibiting (Figure 3C, D). However, when DMBA was added $100 \mathrm{~s}$ after $\mathrm{CaCl}_{2}$, in the presence of 2-APB (Figure 3C), there was a clear and fast decrease of $\left[\mathrm{Ca}^{2+}\right]_{i}$ to values obtained when DMBA is used alone (Figure 3D). Inversely, when 2-APB was added $100 \mathrm{~s}$ after $\mathrm{CaCl}_{2}$ adding in presence of DMBA (Figure 3D), there was no increase of $\left[\mathrm{Ca}^{2+}\right]_{\mathrm{i}}$. Thus, DMBA could impair 2-APB-induced potentiation of SOCE, whereas 2-APB could not avoid DMBA-induced inhibition of SOCE. This shows that DMBA inhibits the SOCE and can bypass the 2-APBdependent potentiation.

Last we tested phenylboronic acid (PBA, 6; Figure 1), which can be considered as a hemi-diphenylborinic acid. PBA was devoid of either potentiating or inhibitory activity on SOCE (Figure 3E), suggesting that the two phenyl or mesityl rings must be on the same boron atom to give activity to the 2-APB analogue.

\section{2-APB analogues without the B-O core are not able to potentiate SOCE}

Thus, compounds containing a terminal B-OH (DMBA and $\mathrm{PBA}$ ) do not appear to behave like compounds containing a central B-O ("BOC", 2-APB, DPBA and $2-A B B)$, suggesting a requirement of the $B O C$ for the potentiating activity of 2 -APB analogues. To confirm this hypothesis, we performed experiments with 2-APB 
A
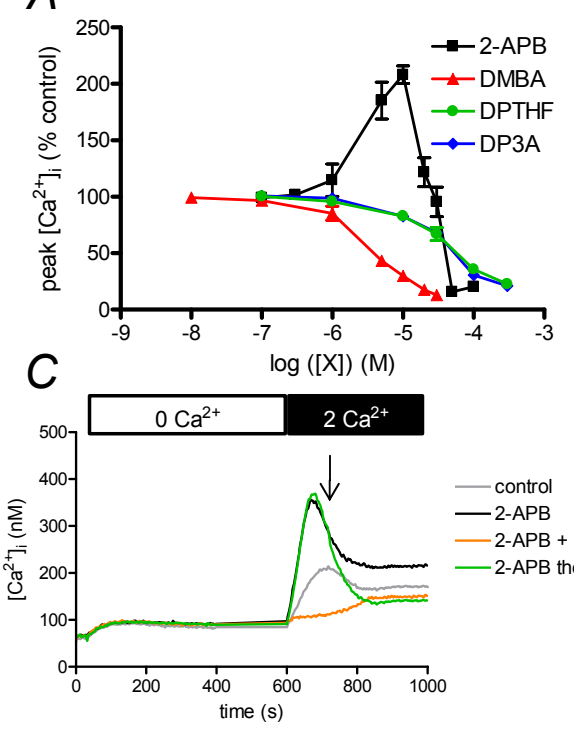

E
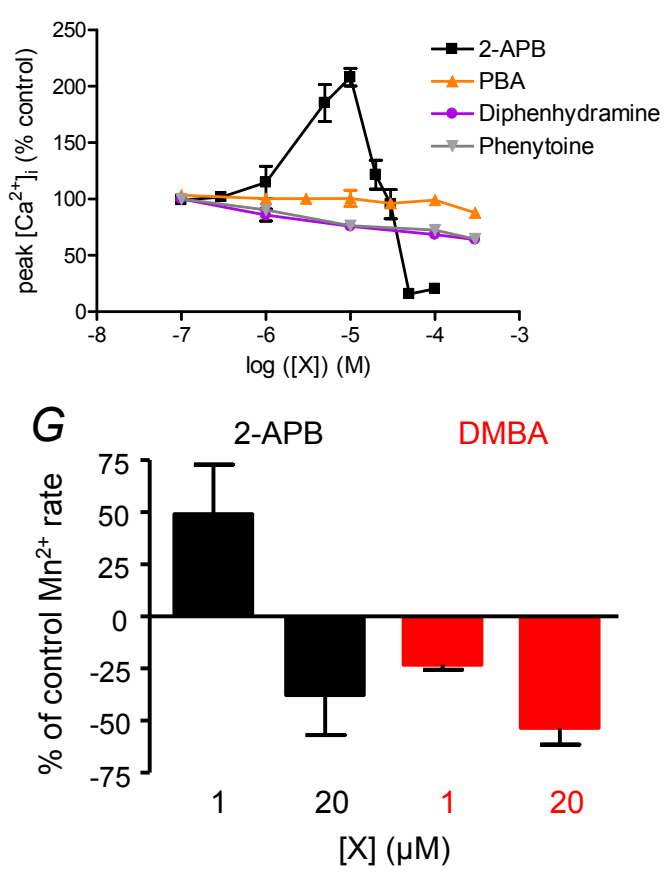

$B$

TG $1 \mu \mathrm{M}$
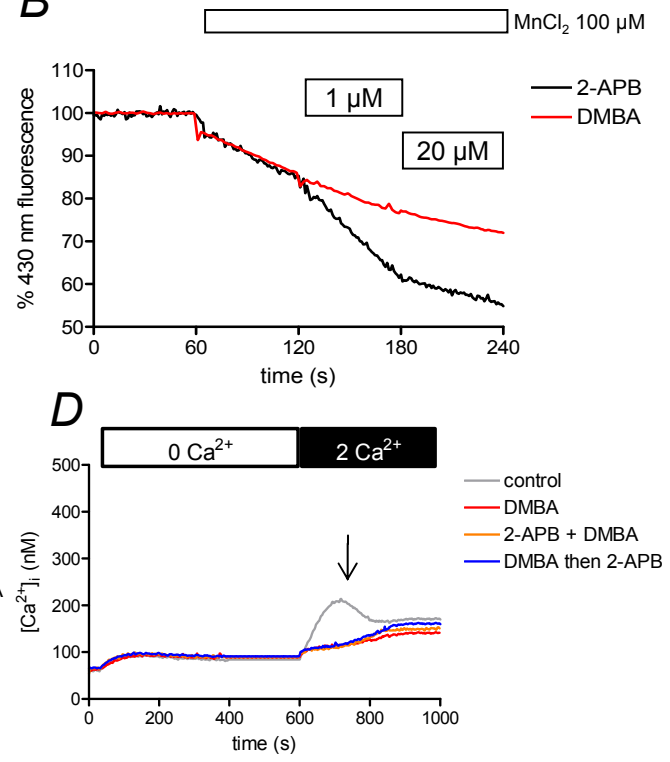

$F$

TG $1 \mu \mathrm{M}$
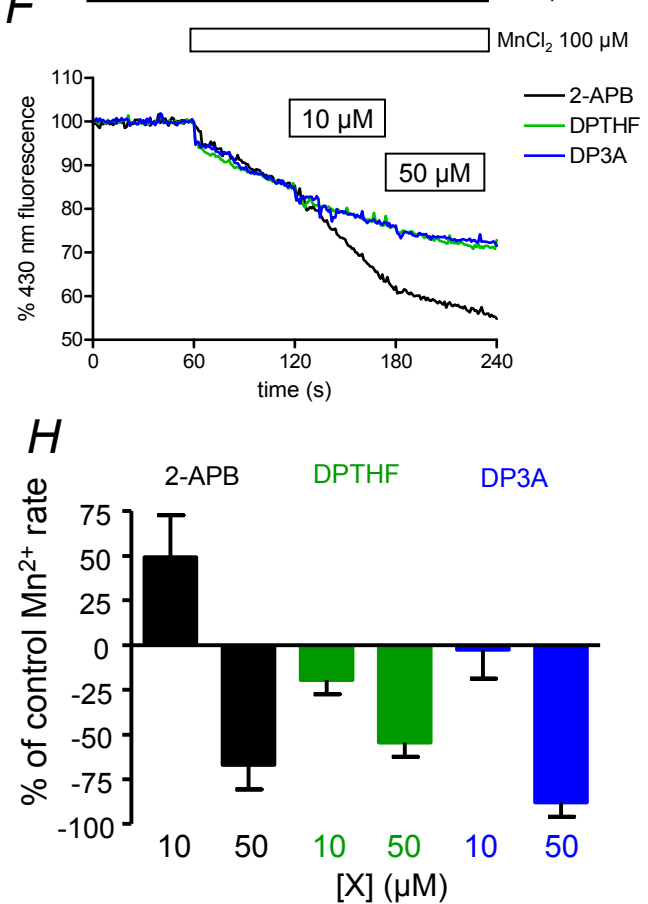

Figure 3 Non-borinate esters are either uneffective or inhibitors of SOCE. Dose-response curve of $\left[\mathrm{Ca}^{2+}\right]_{\mathrm{i}}$ to $2-\mathrm{APB}$ analogues were obtained as in figure 2C. A. DMBA, DPTHF and DP3A are inhibitors of SOCE. B. Mn ${ }^{2+}$ quenching of indo- 1 in BL41 cells stimulated by two concentrations of DMBA or 2-APB. Same as in figure 2B, except that 1 and $20 \mu \mathrm{M}$ DPBA or 2-APB were used. C and D. Cytosolic calcium concentration measurement of BL41 cells in 2-APB/DMBA competition experiments. Cells were treated 400s with TG $1 \mu \mathrm{M}$ to allow Ca2+ release from ER and opening of SOC channels. Then 1 mM CaCl 2 was added, allowing Ca ${ }^{2+}$ entry through SOC channels. 2-APB 10 MM ("2-APB", C), DMBA $10 \mu \mathrm{M}$ ("DMBA", D) or 2-APB $10 \mu \mathrm{M}+\mathrm{DMBA} 10 \mu \mathrm{M}$ ("2-APB + DMBA", C and D) were applied $30 \mathrm{~s}$ prior to CaCl . In competition experiments, DMBA $10 \mu \mathrm{M}$ was applied $100 \mathrm{~s}$ after $\mathrm{CaCl}_{2}$ adding on cells treated by 2-APB ("2-APB then DMBA", C) or 2-APB $10 \mu \mathrm{M}$ was applied $100 \mathrm{~s}$ after $\mathrm{CaCl}_{2}$ adding on cells treated by DMBA ("DMBA then 2-APB", D). Error bars were omitted for clarity (maximum 50 nM). E. Diphenhydramine and phenytoine are weak inhibitors of SOCE, although PBA is inefficient. Same experiment as done in figure $3 \mathrm{~A}$. F. Mn ${ }^{2+}$ quenching of indo-1 in BL41 cells by low and high concentrations of DPTHF and DP3A, compared to 2-APB. Same protocol was used as in figure $2 \mathrm{~B}$. The two analogues were used at $10 \mu \mathrm{M}$ and $50 \mu \mathrm{M}$. G and $\mathrm{H}$. Values of Indo-1 quenching in presence of the borinate esters were normalised to values obtained in the lonely presence of $\mathrm{Mn}^{2+}$ ions, respectively from $\mathrm{B}$ and $\mathrm{F}$. 
analogues devoid of B-O. Several of these analogues (Phenytoin, diphenhydramine, DPTHF) have been tested on platelet SOCE and described as inhibitors [23]. It has been hypothesized that the terminal amine and the boron of 2-APB could form an internal coordinatebound, resulting in the formation of a ring ("close" or "ring", [23]).

Diphenhydramine (7; Figure 1), an analogue without boron and where the terminal amine bears two methyl groups cannot form the internal coordinate (analogue of the "open" form of 2-APB). Phenytoine (8; Figure 1) is an analogue with a third ring containing two ketone groups and two nitrogen atoms (analogue of the "ring" form of 2-APB). Diphenhydramine and phenytoin were weak inhibitors of BL-41 SOCE (with a maximum of $35 \%$ at $300 \mu \mathrm{M})$, and totally devoid of potentiation ability, as previously described on platelets ([23], Figure 3E).

2,2-diphenyltetrahydrofuran (DPTHF (3; Figure 1)), an analogue of the 2 -APB ring form with a more neutral third ring, was a more effective inhibitor with a $K_{i} \sim$ $50 \mu \mathrm{M}$, but was totally devoid of potentiating ability (Figure 3A), as in platelets [23]. At $10 \mu \mathrm{M}$, DPTHF was a slight inhibitor $(-0.11 \pm 0.00 \% / \mathrm{s} v \mathrm{~s} .-0.16 \pm 0.01 \% / \mathrm{s})$, more efficient at $50 \mu \mathrm{M}(-0.06 \pm 0.00 \% / \mathrm{s} v s .-0.16 \pm$ $0.01 \% / \mathrm{s}$ ) when used in $\mathrm{Mn}^{2+}$ quenching experiments of indo-1 (Figure 3F).

3-(diphenylphosphino)-1-propylamine (DP3A (9; Figure 1)) is a $2-\mathrm{APB}$ analogue where the $\mathrm{BOC}$ is replaced by a carbon-phosphorus core. This little change resulted in drastic consequences: DP3A was only inhibitory, with a $K_{i}$ similar to DPTHF's (Figure 3A). In indo-1 quenching experiments by $\mathrm{Mn}^{2+}$ ions, DP3A was a weak inhibitor at $10(-0.11 \pm 0.02 \% / \mathrm{s} v s .-0.18 \pm 0.03 \% / \mathrm{s})$ and $50 \mu \mathrm{M}$ $(-0.05 \pm 0.02 \% / \mathrm{s} v s .-0.18 \pm 0.03 \% / \mathrm{s})$, confirming its total absence of potentiating effect on the divalent ion influx (Figure 3F). Although DPTHF and DP3A were only inhibitory, they were also less efficient, as higher concentrations were needed to get the same inhibition as done by 2 -APB (Figure 3A). This also confirms that the BOC is not an absolute requirement to confer the inhibitory ability of the compound.

Dual effects of borinate esters (2-APB, DPBA and 2-ABB) are observed in other leukemia/lymphoma cell lines As the most extensively studied SOCE is CRAC of T lymphocytes [17] we tested whether the identified structure effects of 2-APB analogues were also relevant to T cells and other cell lines. As previously shown, 2-APB has dual effect on Jurkat cell SOCE, potentiation at $3 \mu \mathrm{M}$ and inhibition at $>20 \mu \mathrm{M} 2-\mathrm{APB}$ (Figure 4A). SOCE of monocytic U937 cells was potentiated and inhibited by 2 $\mathrm{APB}$ in a similar way to BL-41 SOCE: potentiation at $10 \mu \mathrm{M}$, inhibition at $>50 \mu \mathrm{M}$ (Figure 4A). Thus, the
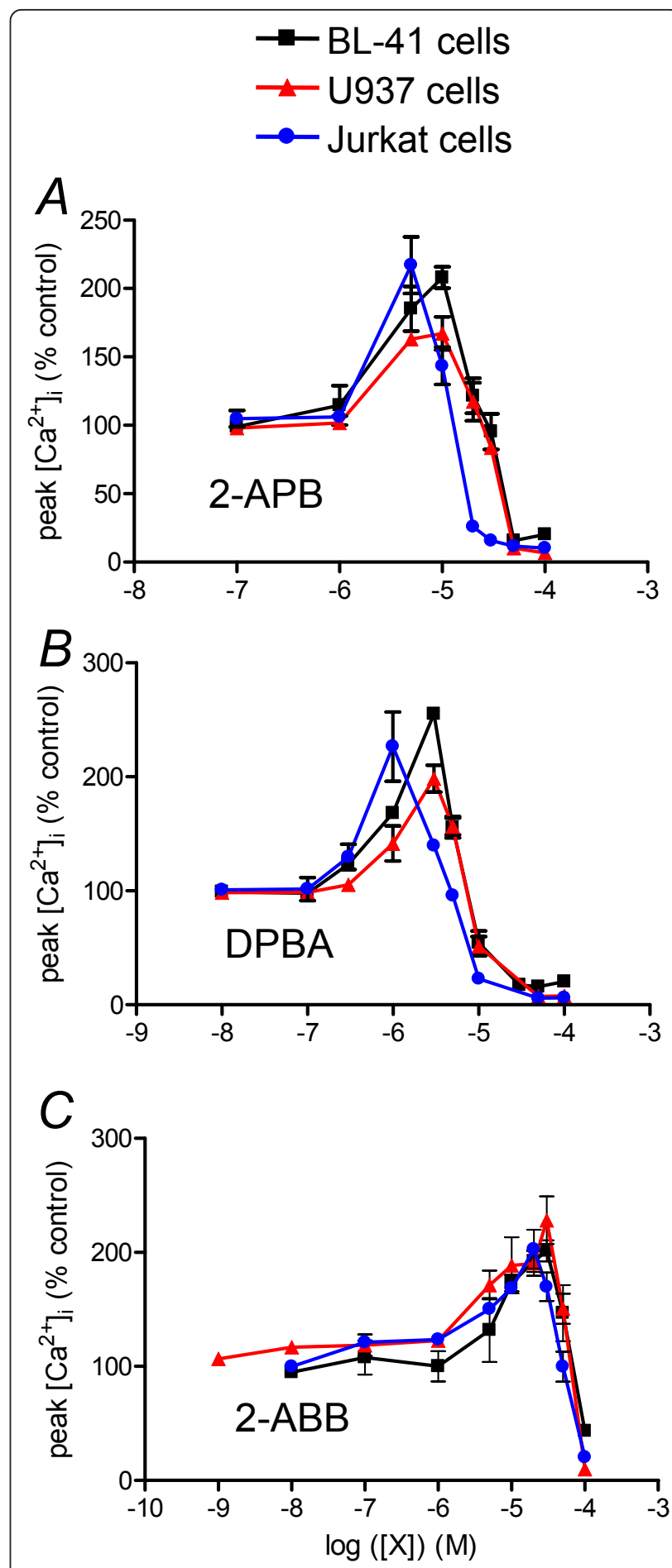

Figure 4 Borinate esters have dual effects on SOCE of myeloid and lymphoid hematopoietic cells. Dose response curves for 2APB (A), DPBA (B) and 2-ABB (C) obtained on SOCE of BL-41, U937 and Jurkat cells. Same protocol was used as in figure $2 \mathrm{~A}$ to generate the dose-response curve of $\left[\mathrm{Ca}^{2+}\right]_{i}$ increase after $\mathrm{Ca}^{2+}$ readding to borinate compound concentrations. Values are expressed as $\%$ of the peak $\left[\mathrm{Ca}^{2+}\right]_{\mathrm{i}}$ increase measured in absence of any effector. 
2-APB dose-response curve obtained on Jurkat cell SOCE showed a leftward shift, indicating a near three-fold higher sensitivity to 2-APB than B lymphocyte BL41's and monocytic U937's. Dose-response curves obtained with BL30 (Burkitt lymphoma B cell line), THP1 (monoblastic cell line) and NB4 cells (promyelocytic cell line) were similar to BL41's and U937's (not shown). These results indicate that the previously reported effects of 2-APB on human T cell SOCE [17] can also be observed in other cell types of hematopoietic origin.

DPBA was also 3 fold more efficient than 2-APB in Jurkat and U937 cells (Figure 4B). Remarkably, Jurkat cells remained three times more sensitive to DPBA than the other cell lines, as with 2-APB (Figure 4B).

$2-\mathrm{ABB}$ had the same dual effect on U937 and Jurkat cell SOCE (Figure 4C). As with BL41 cells, U937 and Jurkat cells were 2-3 fold less sensitive to 2-ABB than to 2-APB (Figure 4C). Like with 2-APB and DPBA, Jurkat cell SOCE was three-fold more sensitive to the 2-ABB than BL41 and U937 SOCE. Thus, Jurkat cell SOCE is 2-3 fold more sensitive to borinic ester potentiation and inhibition than other cell SOCE.

\section{Orai isoform expression}

SOCE is directly dependent on Orai protein expression. Three Orai isoforms have been characterized in human cells and exhibit different sensitivities to 2-APB when over-expressed in HEK 293 cells [28]. We studied Orai isoform expression in our cell lines by using qRT-PCR. As shown in Figure 5, the three cell lines expressed different amounts and ratio of the three isoforms. Thus, although Orai1 is the main isoform in Jurkat $\mathrm{T}$ cells at the mRNA scale (with low amount of Orai2 and 3), Orai2 is the main isoform in BL41 B cells and U937 monocytic cells express mainly Orai3, with a slightly weaker amount of Orai2. Noteworthy, BL41 B cells do not express Orai3. Thus, the

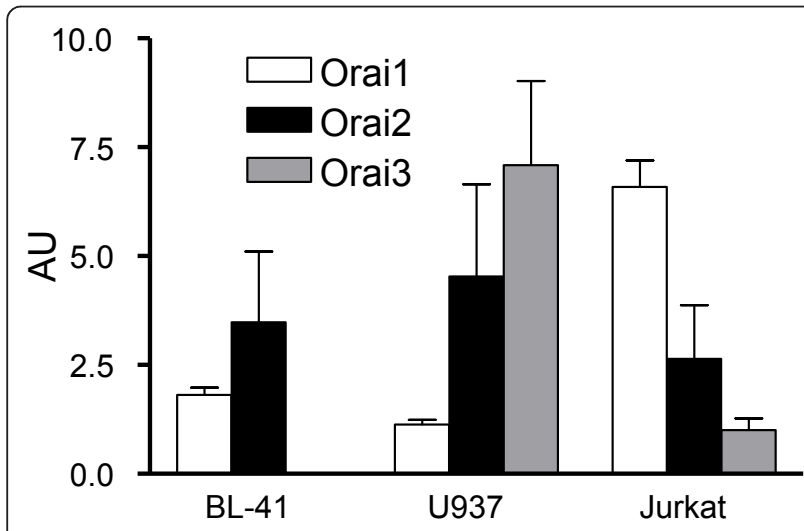

Figure 5 Orai isoform mRNA are differently expressed in hematopoietic cells. QRT-PCR results were expressed as arbitrary units with expression of Orai3 in Jurkat equal 1. See material and methods for details. difference of Orai expression could be responsible of the sensitivity difference to 2-APB/borinate ester dual effects in our cell lines. Even if the Orail mRNA is not the main Orais mRNA, the SOCE is almost abolished at [2-APB] > $50 \mu \mathrm{M}$ in the three cell lines, meaning Orai1 proteins form the main channel.

\section{Borinate esters are also $\mathrm{Ca}^{2+}$ release inhibitors}

To test the SOCE-specificity of the 2-APB analogues, we performed the same kind of experiment, except that the cells were stimulated with an anti-IgM antibody instead TG. In these conditions, anti-IgM antibodies induce synthesis of $\mathrm{IP}_{3}$ and $\mathrm{Ca}^{2+}$ ion release through $\mathrm{IP}_{3}$ receptor of the ER [29]. At their maximal SOCE potentiation concentration, the three borinate esters already impaired the $\mathrm{Ca}^{2+}$ release by the ER (Figure 6A).

DMBA at 10 (not shown) and $20 \mu \mathrm{M}$ was also able to totally block the $\mathrm{Ca}^{2+}$ release by the ER, in a range of concentration similar to concentration needed to block the SOCE (Figure 6B). In contrast, at a concentration with almost no effect on SOCE (Figure 3A), $10 \mu \mathrm{M}$ DP3A tightly blocked the $\mathrm{Ca}^{2+}$ release (Figure 6B).
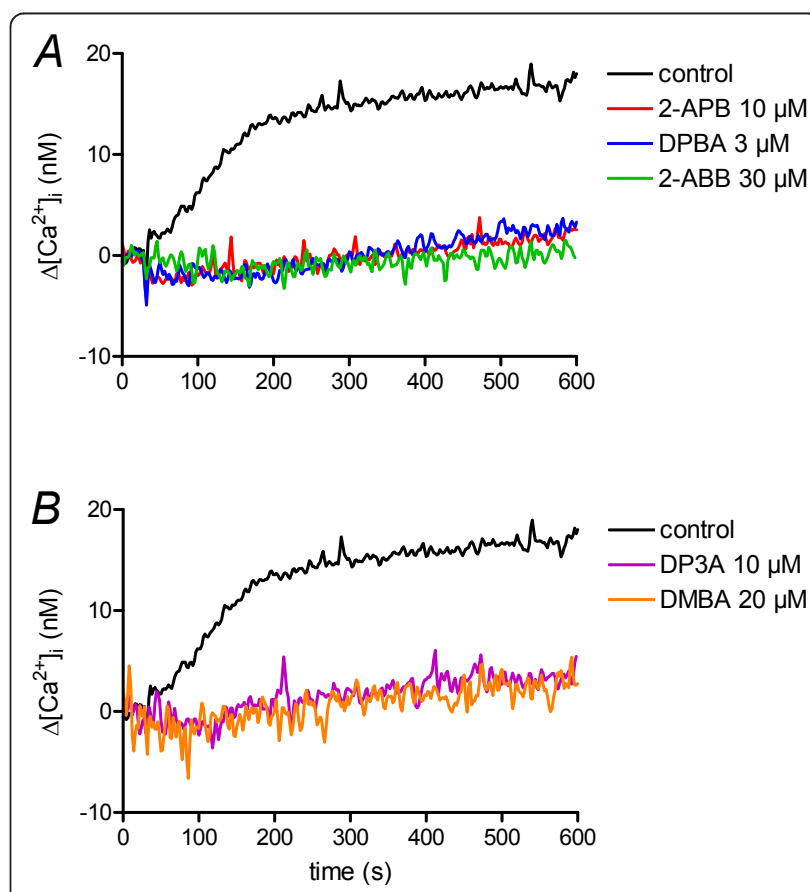

Figure 6 2-APB and analogues are $\mathrm{Ca}^{2+}$ release inhibitors. BL-41 cell cytosolic concentrations were measured as in figure 1. To induce $\mathrm{Ca}^{2+}$ release by the ER, cells were treated with $0.5 \mu \mathrm{g} / \mathrm{ml}$ anti-lgM antibody at $t=30 \mathrm{~s}$. According to the treatment, cells were pre-treated with 2-APB or analogues during 5 min prior antiIgM antibody stimulation. Error bars were omitted for clarity but were $<4 \mathrm{nM}$. 


\section{Discussion}

In this work, we clearly show that 2-APB is able to exert dual effects (potentiation and inhibition) on the $\mathrm{Ca}^{2+}$ influx of various cell lines of hematopoietic origin, and may be considered as the parent of a new family of molecules with this dual efficacy. We were able to define which part of the 2-APB molecule is required for potentiation and/or inhibition of the $\mathrm{Ca}^{2+}$ influx through store-operated channels. Despite the same kind of activity in hematopoietic cell lines, a slight difference in sensitivity to 2-APB and its analogues can be observed, and could be due to the relative expression of the three Orai proteins.

Though 2-APB is a small molecule, three parts can be distinguished: an ethanolamine chain, a boron-oxygen core (BOC) and two phenyl rings. The presence of a boron atom with an amine chain allows the formation of an internal coordinate, but the boron atom is also able to interact with $\mathrm{N}$ and $\mathrm{O}$ atoms of amino-acids, as shown in the case of bortezomib binding to proteasome [30]. The use of analogues helped to understand which part of the 2-APB is important to inhibit SOCE of platelets $[22,23]$, but nothing was known about the potentiation process, as platelet SOCE is clearly not potentiated by 2 -APB and analogues.

DPBA had been previously used and was known as a five fold more potent inhibitor of platelet SOCE than 2APB $(2 \mu \mathrm{M} v s .10 \mu \mathrm{M},[23])$, meaning the ethanolamine group plays no role in SOCE inhibition (and the N-B internal coordinate bond as well). DPBA could also activate some TRP channels at concentrations $>100 \mu \mathrm{M}$ [31,32]. In our experiments, DPBA is $\sim 3$ fold more efficient than 2-APB, and is able to potentiate the $\mathrm{Ca}^{2+}$ influx. Thus, $\left[\mathrm{Ca}^{2+}\right]_{\mathrm{i}}$ variations are increased by $200-$ $250 \%$ at $3-10 \mu \mathrm{M}$, concentrations without any known effect on TRP channels. As DPBA does not possess an ethanolamine group, this confirms that this group plays no role in potentiation process.

2-ABB, a compound never used in $\mathrm{Ca}^{2+}$ signalling, is an analogue of 2 -APB where the two phenyl groups were replaced by two butyl. On the three cell lines, we found that 2-ABB, like 2-APB and DPBA, has dual effect on $\mathrm{Ca}^{2+}$ influx, meaning that the two phenyl rings are not an absolute requirement for potentiation and inhibition processes. However, $2-\mathrm{ABB}$ is less potent to potentiate AND inhibit SOCE than 2-APB and DPBA. A clear correlation seems to exist between the number of phenyl rings in the molecule and its ability to potentiate/inhibit SOCE: DPBA (4 phenyl groups) > 2-APB (2) $>2$-ABB (0). Thus, it seems that the phenyl rings do not play a direct role in potentiation, but rather favour it. We can assess that after the binding of 2-APB to the channel protein by the $\mathrm{BOC}$, the two phenyl rings strengthen the binding by a second interaction. In
DPBA, the presence of four phenyl rings reinforces this binding. It was previously shown that addition of a phenyl ring to the 2-APB molecule could increase its inhibitory efficacy on platelet SOCE [22]. Dimers of 2-APB (with four phenyl rings) had been recently shown to have higher ability to inhibit SOCE than 2-APB [25].

It is also remarkable that the ratio between the concentrations of compound to have maximal potentiation, and to have inhibition is similar with the three borinate esters (from BL41 cells, but same kind from Jurkat and U937 cells): 2 -APB $10 \mu \mathrm{M} / 100 \mu \mathrm{M}$, DPBA $3 \mu \mathrm{M} / 30 \mu \mathrm{M}$, 2-ABB $30 \mu \mathrm{M} / 200 \mu \mathrm{M}$ (this last value was extrapolated from graphs): this clearly shows that potentiation and inhibition are linked. Interestingly, 2-ABB is the first described SOCE inhibiting molecule without any structural rings.

Sensitivity to potentiation/inhibition by borinate esters varies among cell line SOCE: thus, these compounds are three fold more potent on Jurkat cell SOCE. Using qRTPCR, we showed the the cell lines used in this study do not express the same Orai proteins, and in different ratios (Figure 5). Thus we confirmed that the main Orai protein expressed by Jurkat $\mathrm{T}$ cells is Orai1 [4], although BL41 cells express mainly Orai2, and U937, a mix of Orai2 and Orai3 (Figure 5). Of note, in B cells from patient with a non-functional Orail inducing a SCID, SOCE is not abrogated as in $\mathrm{T}$ cells, but decreased, allowing a partial NF-AT activation $[4,33]$. This could be due to the fact that $\mathrm{B}$ cells express significantly more Orai2 than Orai1 proteins, and Orai2 proteins could play a role in B cell SOCE. However the role of Orai2 (and Orai3) in SOCE is controversial: although Orai2 (and Orai3) could form SOCE when over-expressed with STIM1 in HEK293 cells [28], heterologous expression of Orai2 in SCID T cells cannot restore SOCE [8]. While Orai1 has been clearly shown to encode the SOC pore in many cells, a recent work showed that Orai3 is the SOC pore of estrogen receptor positive breast cancer cell lines, in contrast to estrogen receptor negative cell line which use Orai1 [34]. The role of transient receptor potential canonical protein (TRPC) in forming store operated channels with Orai1 protein is also controversial: some authors show a clear association [35,36], when others found none [37]. As 2-APB is a known inhibitor of TRPC1, 3 and 6 channels [21], we cannot rule out that in B cells, TRPC proteins form the storeoperated channel pore in association with Orai1, and play a role in the SOC pharmacology.

Since the molecular characterization of Orai1 [4], Orai proteins have been fully studied in heterologous expression system $[8,28]$. Although these systems allow easier characterization, due to larger currents, they should be used with care. Thus, in one of the first studies 
reconstituting SOCE with Orai1 and STIM1 overexpression in HEK293 cells, it was shown that 2-APB was able to inhibit SOCE but not to enhance it (Figure $1 \mathrm{C},[38])$. Thus, in over-expressing system with large amount of Orai1 and STIM1 proteins, inducing large increase of $\left[\mathrm{Ca}^{2+}\right]_{\mathrm{i}}(3500 \mathrm{nM}), 2$-APB is not potentiating. Furthermore, the expression levels of Orai1 and STIM1 have been shown to affect the $\mathrm{Ca}^{2+}$ conductance and the potentiation of the currents by 2-APB [39]. The use of recombinant Orai/STIM seems to be accurate for the study of drugs with inhibition ability, but not for drugs with potentiating ability. Furthermore, SOCE is a large family, with different kinetics and pharmacological properties, and the expression of Orai1 and STIM1 can not reconstitute the different types of SOCE, because all the partners forming a SOC are not known yet (TRPC proteins? other ?). The use of cell lines to study the pharmacology is complementary to the use of recombinant system, but crucial to identify new compounds with potentiating ability.

The presence of a boron-oxygen link in a molecule does not mean that a compound has potentiating ability on SOCE. DMBA, which resembles 2-APB without the ethanolamine group but a terminal hydroxyl group bound to the boron atom, has shown great capacity to block SOCE, without any potentiating effect. The dipeptidyl boronate pyrazylcarbonyl-Phe-Leu-boronate, also known as PS-341 or bortezomib (commercial name: Velcade $^{(\mathbb{B}}$ ) is a well known inhibitor of proteasome used in the treatment of multiple myeloma. Its pharmacophore is a terminal boron atom with two hydroxyl groups $[40,41]$. Bortezomib blocks protein degradation by binding to the terminal threonine of $20 \mathrm{~S}$ core particle with a $K_{\mathrm{i}}<1 \mathrm{nM}[40,42]$. Remarkably, the same molecule without the boron atom ("aldehyde form") largely loses its proteasome inhibitory capacity $\left(K_{\mathrm{i}}=1.6 \mu \mathrm{M}\right)$ [42]. Boron atom presence is also an absolute requirement in serine protease inhibitors [43]. Thus, the same kind of relationship seems to exist between SOC protein/2-APB and proteasome/bortezomib.

The absolute requirement of the boron atom for potentiation was confirmed by DP3A. Despite its closely related structure to 2-APB', DP3A had never been used in $\mathrm{Ca}^{2+}$ signalling before this work. Remarkably, this compound where a $\mathrm{P}-\mathrm{C}$ core replaces the $\mathrm{BOC}$ present in 2-APB, has lost its ability to potentiate SOCE of hematopoietic cell lines (Figure 3A and 3D). This result clearly highlights the key role of the $\mathrm{BOC}$ in the potentiation ability of 2-APB. However, DP3A is still inhibitory even if higher concentrations are needed to inhibit SOCE than 2 -APB. Thus, replacement of the BOC in the 2-APB molecule impairs the ability of the molecule to potentiate SOCE and decrease its capability to inhibit it. It also confirms that the $\mathrm{BOC}$ is not required for a molecule to be inhibitory, as shown previously with DPTHF [23] and in the present work (Figure 3A and 3D).

The dual effect of borinate esters on SOCE is complex to analyse because the binding sites of 2-APB are not clearly established yet. Thus, before the discovery of Orail, the study of the $\mathrm{T}$ cell SOCE, characterized the dual effect of 2-APB and the authors hypothesize the existence of two binding sites, one potentiating with high affinity, the other one with lower affinity and inhibitory [17]. The inhibitory target of 2-APB seems to be STIM1 itself [44], but 2-APB can also bind to the selectivity filter of the Orai protein, widening the size of the pore, resulting in potentiation of the current [45]. However, the same authors provide an alternative explanation where 2-APB interacts with the CRAC channels to widen the channel pore, and when more 2-APB interact with the channel, a change of channel conformation may prevent ions to pass through it. Furthermore, SOC are made with four Orai proteins, meaning a SOC has potentially four 2-APB binding sites, and nothing is known yet about how many 2 -APB molecules are required to widen the pore or to block it. Our work could provide new tools to study 2-APB binding sites. Thus, DMBA is a compound able to counteract the potentiating effect of 2 -APB. Our preliminary results with DMBA/2-APB competition could not explore the binding sites of the molecules, but we could make two main hypothesis: (i) DMBA and 2-APB have the same binding site. As DMBA impaired 2-APB potentiating effect, and 2-APB can not remove the DMBA inhibition, we could think that DMBA has a higher affinity for the binding site than 2-APB. (ii) DMBA and 2-APB have two different binding sites and binding to the inhibitory binding site (STIM1 ?) bypasses the potentiation binding site. Interesting is the case of Orai3: Orai3 channels do not need stimulation by STIM1 to be opened, and 2APB has only potentiating ability. If DMBA binds to STIM1, it should have no effect on Orai3 currents. Recently, it has been discovered for the first time that a physiological SOCE could be mediated by Orai3 proteins (usually Orai1' are, [34]). It will be therefore interesting to test the effect of DMBA on these breast cancer cells.

However, all the compounds used in this study are not SOCE specific, as they also exert ability to inhibit the $\mathrm{Ca}^{2+}$ release by the ER. Thus, when borinate esters are at their maximal potentiating concentration, they are already at a concentration fully inhibiting the $\mathrm{Ca}^{2+}$ release (Figure 6), impairing their future use as specific immune-modulator.

\section{Conclusion}

The results from the present study clearly highlight the role of the Boron-Oxygen core in the ability of borinate 
ester molecules to potentiate $\mathrm{Ca}^{2+}$ entry in hematopoietic cells. The design of potentiating compounds requires the absolute presence of a $\mathrm{BOC}$, whereas design of inhibitors does not. Strikingly, terminal B-OH could give high inhibitory ability to molecules (DMBA). This work could represent the first step for the development of new molecules with immunomodulatory properties: thus, a potentiating compound could be useful to enhance responses of blood cells from immunodeficient patients, or to increase $\mathrm{Ca}^{2+}$ toxicity in leukemia cells.

\section{Methods}

\section{Cell lines}

The BL30 and BL41 (Burkitt B lymphomas), Jurkat (acute T cell leukemia), U937 and THP1 (monocytic cell lines) and NB4 (promyeloid leukaemia cell line) cell lines were maintained in RPMI-1640 medium (Lonza, Verviers, Belgium) supplemented with $10 \%$ fetal calf serum and $2 \mathrm{mM}$ ultraglutamine (Invitrogen, Cergypontoise, France), at $37^{\circ} \mathrm{C}$ in a $5 \% \mathrm{CO}_{2}$ humidified atmosphere. All cell lines used were from ATCC-LGC Promochem (Molsheim, France) except BL-30 and BL41 cells which were a gift of Irene Joab [46].

\section{Measurement of intracellular $\mathrm{Ca}^{2+}$ concentration $\left(\left[\mathrm{Ca}^{2+}\right]_{\mathrm{i}}\right)$} The intracellular $\mathrm{Ca}^{2+}$ concentration was recorded by a fluorimetric ratio technique. Cells were centrifugated and resuspended in Phosphate Buffer Saline medium (PBS, Cambrex, Belgium) supplemented with $1 \mathrm{mg} / \mathrm{ml}$ Bovine Serum Albumine (Sigma, Saint Quentin Fallavier, France) under gentle agitation. The fluorescent indicator indo-1 was loaded by incubating the cells at room temperature for $1 \mathrm{~h}$ with $4 \mu \mathrm{M}$ indo-1-AM (Invitrogen/ Molecular Probes, Eugene, USA). Cells were then spinned and resuspended in Hepes Buffer Saline (HBS) medium without $\mathrm{CaCl}_{2}$ (in $\mathrm{mM}$ ): $135 \mathrm{NaCl}, 5.9 \mathrm{KCl}, 1.2$ $\mathrm{MgCl}_{2}$, Hepes 11.6, glucose 11.5, pH 7.3 adjusted with $\mathrm{NaOH}$.

One million cells were put in a $1 \mathrm{~cm}$ width $-3 \mathrm{ml}$ quartz cuvette, and inserted in a spectrofluorophotometer (RF-1501 Shimadzu Corporation, Japan), equipped with a thermostatted $\left(37^{\circ} \mathrm{C}\right)$ cuvette holder. Ultraviolet light of $360 \mathrm{~nm}$ was used for excitation of indo-1, and emission at 405 and $480 \mathrm{~nm}$ were recorded. Background and autofluorescence of the cells were removed from the values measured at 405 and $480 \mathrm{~nm}$. The maximum indo- 1 fluorescence $\left(R_{\max }\right)$ was obtained by adding $1 \mu \mathrm{M}$ ionomycin to the bath in the presence of $10 \mathrm{mM} \mathrm{CaCl} 2$. Minimum fluorescence $\left(R_{\min }\right)$ was determined following depletion of external $\mathrm{Ca}^{2+}$ by 5 mM EGTA. All the measures were sent to a PC computer and analyzed. $\left[\mathrm{Ca}^{2+}\right]_{\mathrm{i}}$ was calculated according to the equation $\left[\mathrm{Ca}^{2+}\right]_{\mathrm{i}}=\mathrm{Kd}\left(\mathrm{R}-R_{\min }\right) /\left(R_{\max }-\mathrm{R}\right)$, where $K \mathrm{~d}$ is the apparent dissociation constant of indo-1 for $\mathrm{Ca}^{2+}$
(250 nM, [47]), and $\mathrm{R}$ is the ratio of fluorescence value at $405 \mathrm{nM}$ on the one at $480 \mathrm{~nm}$ [47].

To induce SOCE, the cells were treated for $10 \mathrm{~min}$ with $1 \mu \mathrm{M}$ TG in the absence of external $\mathrm{Ca}^{2+}$. After 10 min, $1 \mathrm{mM} \mathrm{CaCl}$ was added. For dose-response curves, the peak $\left[\mathrm{Ca}^{2+}\right]_{\mathrm{i}}$ was measured and expressed as a percentage of peak $\left[\mathrm{Ca}^{2+}\right]_{\mathrm{i}}$ measured in absence of the test compound. These experiments were done at least three times, but for clarity, the SEM was not shown on traces, but is less than $1-2 \%$ of the mean.

To calculate the $\mathrm{Ca}^{2+}$ influx rate $\left(\Delta\left[\mathrm{Ca}^{2+}\right]_{\mathrm{i}}\right)$, we measure the variation of $\left[\mathrm{Ca}^{2+}\right]_{i}$ per second during the first $20 \mathrm{~s}$ after $\mathrm{CaCl}_{2}$ addition: in these conditions, the activities of the plasma membrane $\mathrm{Ca}^{2+}$ ATPases (PMCA) and of the $\mathrm{Na}^{+} / \mathrm{Ca}^{2+}$ exchanger are largely reduced (and the activity of SERCA is already inhibited by TG). Thus, the $\Delta\left[\mathrm{Ca}^{2+}\right]_{\mathrm{i}}$ is only due to the $\mathrm{Ca}^{2+}$ ion entry [26].

$\mathrm{Mn}^{2+}$ ion binding to indo-1 forms a non-fluorescent complex. Thus, $\mathrm{Mn}^{2+}$ entry can be estimated by the Indo-1 fluorescence quenching rate [48]. In these experiments, SOCE was activated during $10 \mathrm{~min}$ with 1 $\mu \mathrm{M}$ TG without external $\mathrm{Ca}^{2+}$. Fluorescence of Indo-1 was recorded at $430 \mathrm{~nm}$ emission wavelength (excitation wavelength $360 \mathrm{~nm}$ ). We recorded this fluorescence during 2-3 min, and only cuvettes with a stable value were then used for the quenching experiment. At $t=60$ s, $100 \mu \mathrm{M} \mathrm{MnCl}_{2}$ was added, and the Indo-1 fluorescence quenching was measured, and served as a control value. According to the different experiments, 2-APB or 2 -APB analogues were added at various concentrations, and the quenching rates were normalised to the value obtained in presence of only $\mathrm{Mn}^{2+}$ ions. These experiments were done at least three times, but for clarity, the SEM was not shown on traces, but is less than $1-2 \%$ of the mean.

To test the effects of 2-APB and its analogues on the $\mathrm{Ca}^{2+}$ release by the ER, the BL41 cells were stimulated by an anti-IgM antibody (ABCam, Paris, France) instead by TG, still in absence of extracellular $\mathrm{Ca}^{2+}$. This kind of antibody cross-links to the $\mathrm{B}$ cell receptor induces the synthesis of $\mathrm{IP}_{3}$ and $\mathrm{Ca}^{2+}$ release through $\mathrm{IP}_{3}$ receptors [29]. Cells were pretreated 5 min with 2-APB or an analogue, then stimulated by $0.5 \mu \mathrm{g} / \mathrm{ml}$ anti-IgM antibody. These experiments were done at least three times, but for clarity, the SEM was not shown on traces, but is less than $1-2 \%$ of the mean.

\section{Orai isoform expression}

Total RNA was isolated from cell lines by using the TRIzol $^{\circledR}$ Reagent (Invitrogen) following the manufacturers' instructions. RNA was quantified with Thermo Scientific NanoDrop ${ }^{\mathrm{TM}}$ Spectrophotometers. Reverse transcription was performed on $1 \mu \mathrm{g}$ of total RNA. After 3 min at $95^{\circ} \mathrm{C}$, RNA was incubated for $1 \mathrm{~h}$ at $42^{\circ} \mathrm{C}$ 
with 50 units of M-MLV reverse transcriptase (Applied Biosystems), 20 units of RNase inhibitor (Applied Biosystems), $2.5 \mathrm{mM}$ random hexamers and dNTP at $1 \mathrm{mM}$ in a final volume of $20 \mu \mathrm{l}$. Finally, reverse transcriptase was denatured by heating for $5 \mathrm{~min}$ at $95^{\circ} \mathrm{C}$. We quantified transcripts of the GAPDH gene as the endogenous RNA control. Each sample was normalized on the basis of its GAPDH content, and results expressed as $N$-fold differences in target gene expression relative to the GAPDH gene (termed Ntarget), were determined with the following formula: Ntarget $=2(\Delta C t$ sample $\Delta C t$ calibrator), where the $\Delta C t$ value of the sample was determined by subtracting the average $\mathrm{Ct}$ value of the target gene from the average $\mathrm{Ct}$ value of the GAPDH gene. The Ntarget values of the samples were subsequently normalized such that the mean ratio of the samples with the lowest expression level would have a value of 1 . The nucleotide sequences of the primers used for PCR amplification were as follows:

GAPDH-Forward:

\section{GGACCTGACCTGCCGTCTAGAA}

GAPDH-Reverse: GGTGTCGCTGTTGAAGTCAGAG

ORAI1-Forward: TCGGTCAAGGAGTCCCCCCAT

ORAI1-Reverse: GTCCTGTAAGCGGGCAAACTC

ORAI2-Forward: GCTGAGCTTAACGTGCCTATC

ORAI2-Reverse: GGAGTTCAGGTTGTGGATGTT

ORAI3-Forward: CCCTTAGTCCAGCTTCCAATC

ORAI3-Reverse: CCAAGGAGCGGTAGAAATGCA

PCR was performed using an ABI Prism 7700 Sequence Detection system (Perkin-Elmer Applied Biosystems) and the SYBR ${ }^{\circledR}$ Green PCR Master Mix (Applied Biosystems). The thermal cycling conditions comprised an initial denaturation step at $95^{\circ} \mathrm{C}$ for $10 \mathrm{~min}$ and 40 cycles at $95^{\circ} \mathrm{C}$ for $15 \mathrm{~s}$ and $60^{\circ} \mathrm{C}$ for $1 \mathrm{~min}$. Experiments were performed in duplicates for each data point.

\section{Chemicals}

2-aminoethoxydiphenyl borate (2-APB), 2-aminoethoxydibutyl borate (2-ABB), diphenylboronic anhydride (DPBA), 2,2-diphenyltetrahydrofuran (DPTHF), phenylborinic acid (PBA), 3-(diphenylphosphino)-1-propylamine (DP3A), phenytoin, diphenhydramine, dimesitylborinic acid (DMBA) and 2-aminoethyl dibutylborinate (2-ABB) were from Sigma-Aldrich (Saint Quentin Fallavier, France), thapsigargin was purchased from Calbiochem-Merck (Nottingham, UK). The structure of 2-APB and analogues is given in Figure 1.

\section{Statistical analysis}

Given values are representative of at least 3 independent experiments \pm SEM. When used, a t-test $<0.05$ is considered as significant.

\section{List of abbreviations}

SOCE: Store-operated calcium entry; SOC: Store-Operated Channel; CRAC: Calcium-Release Activated Calcium; IP aminoethoxydiphenylborate (2-aminoethyl diphenylborinate); $\left[\mathrm{Ca}^{2+}\right]_{i}$ : intracellular $\mathrm{Ca}^{2+}$ concentration; ER: endoplasmic reticulum; TRP: transient receptor potential; BOC: boron-oxygen core; TG: thapsigargin; DPBA: diphenylborinic anhydride; DPTHF: 2,2-diphenyltetrahydrofuran; PBA: phenylborinic acid; DP3A: 3-(diphenylphosphino)-1-propylamine; DMBA: dimesitylborinic acid; 2-ABB: 2-aminoethyl dibutylborinate.

\section{Acknowledgements}

The author would like to thank Patricia Krief for her technical help and Béla Papp for helpful talks. This work was financially supported by Association pour la Recherche sur le Cancer and Ligue contre le Cancer (France).

\section{Author details}

'INSERM UMR-S 940, Institut Universitaire d'Hématologie - Université Denis Diderot Paris 7, Hôpital Saint Louis, Paris, France. ${ }^{2}$ INSERM UMR-S 757, Université Paris Sud 11, Orsay, France.

\section{Authors' contributions}

OD carried out the $\left[\mathrm{Ca}^{2+}\right]_{\mathrm{i}}$ measurements and Orais expression assays, and drafted the manuscript. PM carried out some $\left[\mathrm{Ca}^{2+}\right]_{i}$ measurements and compound tests.

CC conceived and designed the study. All authors have approved the final manuscript

Received: 22 April 2010 Accepted: 26 January 2011

Published: 26 January 2011

\section{References}

1. Berridge MJ: Inositol trisphosphate and calcium signaling. Ann N Y Acad Sci 1995, 766:31-43.

2. Feske $S$, Okamura $H$, Hogan $P G$, Rao A: Ca2+/calcineurin signalling in cells of the immune system. Biochem Biophys Res Commun 2003, 311:1117-1132.

3. Chung SC, McDonald TV, Gardner P: Inhibition by SK\&F 96365 of Ca2+ current, IL-2 production and activation in T lymphocytes. Br J Pharmacol 1994, 113:861-868.

4. Feske S, Gwack Y, Prakriya M, Srikanth S, Puppel SH, Tanasa B, Hogan PG, Lewis RS, Daly M, Rao A: A mutation in Orai1 causes immune deficiency by abrogating CRAC channel function. Nature 2006, 441:179-185.

5. Peinelt C, Vig M, Koomoa DL, Beck A, Nadler MJ, Koblan-Huberson M, Lis A, Fleig A, Penner R, Kinet JP: Amplification of CRAC current by STIM1 and CRACM1 (Orai1). Nat Cell Biol 2006, 8:771-773.

6. Lewis RS: The molecular choreography of a store-operated calcium channel. Nature 2007, 446:284-287.

7. Mercer JC, Dehaven WI, Smyth JT, Wedel B, Boyles RR, Bird GS, Putney JW $\mathrm{Jr}$ : Large store-operated calcium selective currents due to co-expression of Orai1 or Orai2 with the intracellular calcium sensor, Stim1. J Biol Chem 2006, 281:24979-24990.

8. Gwack Y, Srikanth S, Feske S, Cruz-Guilloty F, Oh-hora M, Neems DS, Hogan PG, Rao A: Biochemical and functional characterization of Orai proteins. J Biol Chem 2007, 282:16232-16243.

9. Derler I, Fritsch R, Schindl R, Romanin C: CRAC inhibitors: identification and potential. Expert Opinion Drug Discovery 2008, 3:787-800.

10. Huang YH, Hoebe K, Sauer K: New therapeutic targets in immune disorders: ItpkB, Orai1 and UNC93B. Expert Opin Ther Targets 2008, 12:391-413.

11. Sweeney ZK, Minatti A, Button DC, Patrick S: Small-Molecule Inhibitors of Store-Operated Calcium Entry. ChemMedChem 2009.

12. Maruyama T, Kanaji T, Nakade S, Kanno T, Mikoshiba K: 2APB, 2aminoethoxydiphenyl borate, a membrane-penetrable modulator of Ins (1,4,5)P3-induced Ca2+ release. J Biochem 1997, 122:498-505.

13. Bilmen JG, Wootton LL, Godfrey RE, Smart OS, Michelangeli F: Inhibition of SERCA Ca2+ pumps by 2-aminoethoxydiphenyl borate (2-APB). 2-APB reduces both $\mathrm{Ca} 2+$ binding and phosphoryl transfer from ATP, by interfering with the pathway leading to the Ca2+-binding sites. Eur J Biochem 2002, 269:3678-3687.

14. Missiaen L, Callewaert G, De Smedt H, Parys JB: 2-Aminoethoxydiphenyl borate affects the inositol 1,4,5-trisphosphate receptor, the intracellular 
$\mathrm{Ca} 2+$ pump and the non-specific $\mathrm{Ca} 2+$ leak from the non-mitochondrial Ca2+ stores in permeabilized A7r5 cells. Cell Calcium 2001, 29:111-116.

15. Peppiatt CM, Collins TJ, Mackenzie L, Conway SJ, Holmes AB, Bootman MD, Berridge MJ, Seo JT, Roderick HL: 2-Aminoethoxydiphenyl borate (2-APB) antagonises inositol 1,4,5-trisphosphate-induced calcium release, inhibits calcium pumps and has a use-dependent and slowly reversible action on store-operated calcium entry channels. Cell Calcium 2003, 34:97-108.

16. Kukkonen JP, Lund PE, Akerman KE: 2-aminoethoxydiphenyl borate reveals heterogeneity in receptor-activated $\mathrm{Ca}(2+)$ discharge and storeoperated $\mathrm{Ca}(2+)$ influx. Cell Calcium 2001, 30:117-129.

17. Prakriya $\mathrm{M}$, Lewis RS: Potentiation and inhibition of $\mathrm{Ca}(2+)$ releaseactivated $\mathrm{Ca}(2+)$ channels by 2 -aminoethyldiphenyl borate (2-APB) occurs independently of IP(3) receptors. J Physiol 2001, 536:3-19.

18. Ma HT, Venkatachalam K, Parys JB, Gill DL: Modification of store-operated channel coupling and inositol trisphosphate receptor function by 2aminoethoxydiphenyl borate in DT40 lymphocytes. J Biol Chem 2002, 277:6915-6922.

19. Chung MK, Lee H, Mizuno A, Suzuki M, Caterina MJ: 2aminoethoxydiphenyl borate activates and sensitizes the heat-gated ion channel TRPV3. J Neurosci 2004, 24:5177-5182.

20. Hu HZ, Gu Q, Wang C, Colton CK, Tang J, Kinoshita-Kawada M, Lee LY, Wood JD, Zhu MX: 2-aminoethoxydiphenyl borate is a common activator of TRPV1, TRPV2, and TRPV3. J Biol Chem 2004, 279:35741-35748.

21. Lievremont JP, Bird GS, Putney JW Jr: Mechanism of inhibition of TRPC cation channels by 2-aminoethoxydiphenylborane. Mol Pharmacol 2005, 68:758-762.

22. Dobrydneva Y, Abelt CJ, Dovel B, Thadigiri CM, Williams RL, Blackmore PF: 2-aminoethoxydiphenyl borate as a prototype drug for a group of structurally related calcium channel blockers in human platelets. $\mathrm{Mol}$ Pharmacol 2006, 69:247-256.

23. Dobrydneva Y, Blackmore P: 2-Aminoethoxydiphenyl borate directly inhibits store-operated calcium entry channels in human platelets. Mol Pharmacol 2001, 60:541-552.

24. Zhou H, Iwasaki H, Nakamura T, Nakamura K, Maruyama T, Hamano S, Ozaki S, Mizutani A, Mikoshiba K: 2-Aminoethyl diphenylborinate analogues: selective inhibition for store-operated Ca2+ entry. Biochem Biophys Res Commun 2007, 352:277-282

25. Suzuki AZ, Ozaki S, Goto Jl, Mikoshiba K: Synthesis of bisboron compounds and their strong inhibitory activity on store-operated calcium entry. Bioorg Med Chem Lett 2010, 20:1395-1398.

26. Dellis $\mathrm{O}$, Gangloff SC, Paulais M, Tondelier D, Rona JP, Brouillard F, Bouteau F, Guenounou M, Teulon J: Inhibition of the calcium releaseactivated calcium (CRAC) current in Jurkat T cells by the HIV-1 envelope protein gp160. J Biol Chem 2002, 277:6044-6050.

27. Bird GS, Dehaven WI, Smyth JT, Putney JW Jr: Methods for studying storeoperated calcium entry. Methods 2008, 46:204-212.

28. Lis A, Peinelt C, Beck A, Parvez S, Monteilh-Zoller M, Fleig A, Penner R: CRACM1, CRACM2, and CRACM3 are store-operated Ca2+ channels with distinct functional properties. Curr Biol 2007, 17:794-800.

29. Sugawara H, Kurosaki M, Takata M, Kurosaki T: Genetic evidence for involvement of type 1, type 2 and type 3 inositol 1,4,5-trisphosphate receptors in signal transduction through the B-cell antigen receptor. EMBO J 1997, 16:3078-3088.

30. McCormack T, Baumeister W, Grenier L, Moomaw C, Plamondon L, Pramanik B, Slaughter C, Soucy F, Stein R, Zuhl F, Dick L: Active sitedirected inhibitors of Rhodococcus $20 \mathrm{~S}$ proteasome. Kinetics and mechanism. J Biol Chem 1997, 272:26103-26109.

31. Chung MK, Guler AD, Caterina MJ: Biphasic currents evoked by chemical or thermal activation of the heat-gated ion channel, TRPV3. J Biol Chem 2005, 280:15928-15941.

32. Juvin V, Penna A, Chemin J, Lin YL, Rassendren FA: Pharmacological characterization and molecular determinants of the activation of transient receptor potential V2 channel orthologs by 2aminoethoxydiphenyl borate. Mol Pharmacol 2007, 72:1258-1268.

33. Feske $\mathrm{S}$, Giltnane J, Dolmetsch R, Staudt LM, Rao A: Gene regulation mediated by calcium signals in T lymphocytes. Nat Immunol 2001, 2:316-324.

34. Motiani RK, Abdullaev IF, Trebak M: A novel native store-operated calcium channel encoded by Orai3:Selective requirement of Orai3 versus Orai1 in estrogen receptor positive versus estrogen receptor negative breast cancer cells. J Biol Chem 2010.
35. Ambudkar IS, Ong HL, Liu X, Bandyopadhyay BC, Cheng KT: TRPC1: the link between functionally distinct store-operated calcium channels. Cell Calcium 2007, 42:213-223.

36. Liao Y, Erxleben C, Yildirim E, Abramowitz J, Armstrong DL, Birnbaumer L: Orai proteins interact with TRPC channels and confer responsiveness to store depletion. Proc Natl Acad Sci USA 2007, 104:4682-4687.

37. Varga-Szabo D, Authi KS, Braun A, Bender M, Ambily A, Hassock SR, Gudermann T, Dietrich A, Nieswandt B: Store-operated $\mathrm{Ca}(2+)$ entry in platelets occurs independently of transient receptor potential (TRP) C1. Pflugers Arch 2008, 457:377-387.

38. Soboloff J, Spassova MA, Tang XD, Hewavitharana T, Xu W, Gill DL: Orai and STIM reconstitute store-operated calcium channel function. J Biol Chem 2006, 281:20661-20665.

39. Scrimgeour N, Litjens T, Ma L, Barritt GJ, Rychkov GY: Properties of Orai1 mediated store-operated current depend on the expression levels of STIM1 and Orai1 proteins. J Physiol 2009

40. Richardson PG, Hideshima T, Anderson KC: Bortezomib (PS-341): a novel, first-in-class proteasome inhibitor for the treatment of multiple myeloma and other cancers. Cancer Control 2003, 10:361-369.

41. Kisselev AF, Goldberg AL: Proteasome inhibitors: from research tools to drug candidates. Chem Biol 2001, 8:739-758.

42. Adams J, Behnke M, Chen S, Cruickshank AA, Dick LR, Grenier L, Klunder JM, Ma YT, Plamondon L, Stein RL: Potent and selective inhibitors of the proteasome: dipeptidyl boronic acids. Bioorg Med Chem Lett 1998, 8:333-338.

43. Walker B, Lynas JF: Strategies for the inhibition of serine proteases. Cell Mol Life Sci 2001, 58:596-624.

44. Spassova MA, Soboloff J, He LP, Xu W, Dziadek MA, Gill DL: STIM1 has a plasma membrane role in the activation of store-operated $\mathrm{Ca}(2+)$ channels. Proc Natl Acad Sci USA 2006, 103:4040-4045.

45. Peinelt C, Lis A, Beck A, Fleig A, Penner R: 2-Aminoethoxydiphenyl borate directly facilitates and indirectly inhibits STIM1-dependent gating of CRAC channels. J Physiol 2008, 586:3061-3073.

46. Dellis O, Arbabian A, Brouland JP, Kovacs T, Rowe M, Chomienne C, Joab I, Papp B: Modulation of B-cell endoplasmic reticulum calcium homeostasis by Epstein-Barr virus Latent Membrane Protein-1. Mol Cancer 2009, 8:59.

47. Grynkiewicz G, Poenie M, Tsien RY: A new generation of Ca2+ indicators with greatly improved fluorescence properties. J Biol Chem 1985, 260:3440-3450.

48. Nasmith PE, Grinstein S: Phorbol ester-induced changes in cytoplasmic $\mathrm{Ca} 2+$ in human neutrophils. Involvement of a pertussis toxin-sensitive $\mathrm{G}$ protein. J Biol Chem 1987, 262:13558-13566.

doi:10.1186/1471-2210-11-1

Cite this article as: Dellis et al:: The boron-oxygen core of borinate esters is responsible for the store-operated calcium entry potentiation ability. BMC Pharmacology 2011 11:1.

\section{Submit your next manuscript to BioMed Central and take full advantage of:}

- Convenient online submission

- Thorough peer review

- No space constraints or color figure charges

- Immediate publication on acceptance

- Inclusion in PubMed, CAS, Scopus and Google Scholar

- Research which is freely available for redistribution 